\title{
Pepys Island as a Pacific stepping stone: the struggle to capture islands on early modern maps
}

\author{
KATHERINE PARKER*
}

\begin{abstract}
This paper will investigate how geographic features were recorded on maps in the eighteenth century in order to outline the construction of geographic knowledge by British mapmakers. Due to practical and economic factors, early modern cartography was a conservative practice based on source compilation and comparison. For the Pacific region especially, the paucity of first-hand observations and the conflicting nature of those observations rendered the world's largest ocean difficult to chart and prone to the retention of mythical continents, passages and islands. After a discussion of the practical and economic reasons why geographic features were difficult to revise on maps, the article focuses on a case study to show how geographic enigmas could be placed and persist. It will use Pepys Island to illustrate the ways in which a chimeric feature could become instilled in geographic parlance.
\end{abstract}

\section{Introduction}

In the early to mid-eighteenth century, British navigators, officials, intellectuals and entrepreneurs called upon a small body of circulating geographic knowledge in an attempt to access the riches presumed to lie in the Pacific. ${ }^{1}$ They hoped to create itineraries which would allow crews to survive crossing the world's largest ocean while also finding new lands - perhaps the elusive continent of Terra Australis - and trade routes the alluring Northwest Passage. ${ }^{2}$ These itineraries included watering stations and safe anchorages not only in the Pacific itself, but on the approach in both the Atlantic and the Indian Oceans; the early modern Pacific was less geographically fixed in the minds of early modern geographers than it is today. ${ }^{3}$ Locating and charting such Pacific

* The Hakluyt Society. Email: kaparker18th@gmail.com.

I would like to thank the Hakluyt Society, who provided a fellowship that supported the initial research for this paper, as well as the organizers of the Science and Islands in the Indo-Pacific World conference held at Cambridge in September 2016. Their comments, and those of the anonymous reviewers, have helped to improve the article, making any remaining errors or assumptions entirely my own.

1 As this paper focuses on the period spanning the 1707 Acts of Union, this paper will use 'Britain' and 'British' as general terms and will use 'England' and 'English' when specifically discussing events and people prior to 1707.

2 Whereas islands could prove chimeric, the major geographic mysteries of the Pacific were continental: the hypothesized Southern Continent (Terra Australis) and access to the continent of Asia (via a Northwest or Northeast Passage). The literature on the Southern Continent is vast. A recent overview is Ava Judd Stallard, Antipodes: In Search of the Southern Continent, Melbourne: Monash University Publishing, 2016. See also Ann Scott, Alfred Hiatt, Claire Mcllroy and Christopher Wortham (eds.), European Perceptions of Terra Australis, Farnham: Ashgate, 2011. For the Northwest Passage see Glyndwr Williams, Voyages of Delusion: The Quest for the Northwest Passage, New Haven: Yale University Press, 2002.

3 This argument is an extension of the calls by David Igler, Michelle Burnham and others to not view past Pacific worlds through modern categories. They refer to the category of the nation state, but ahistorical 
stepping stones played a central role in the projection of British power into the South Seas in the first decades of the eighteenth century. ${ }^{4}$

Depicting these stepping stones, which were often but not always islands, ${ }^{5}$ was a physical, textual, and visual project that extended from encounters and inscription in the Pacific, to publishing houses in European metropoles, to the individual reactions of readers. While the entire process of geographic knowledge creation deserves study, this paper is concerned with the role of just one group within one part of that wider process of geographic knowledge creation: mapmakers. The writing draughtsman's desk or the engraver's bench - set within a wider network of information sharing that spread across London and extended to other European cities - is used as the site of analysis to better understand how and why specific places were made legible within the British Empire in the eighteenth century.

For several practical and economic reasons, islands proved difficult to chart in the early modern period. ${ }^{6}$ First, sailors had to be trained in chart making, an education that not everyone could afford or access. At sea or during encounters with indigenous peoples onshore, there were the limitations of culture and language, weather, sailing machinery, instruments and navigational technology - the inability to calculate longitude accurately is only the best known of the many challenges facing navigators. ${ }^{7}$ Information then had to travel from ship to metropole, a transmission complicated by the dangers of long-distance sailing, international conflicts and access to materials and publishers - that is, if publication was desired or permitted.

The next step, which will be the focus of the first part of this article, would be to prepare a chart for manuscript presentation or print, a project hindered by the geographic management policies of rival overseas empires, the expense of production and a limited source bank. Furthermore, the personal motivations of mapmakers and the

geographical concepts are also limiting. See David Igler, The Great Ocean: Pacific Worlds from Captain Cook to the Gold Rush, New York: Oxford University Press, 2013, p. 8; Michelle Burnham, 'Trade, time and the calculus of risk in early Pacific travel writing', Early American Literature (2011) 46(3), pp. 425-447, 425.

4 For overviews of the British in the Pacific see Glyndwr Williams, The Great South Sea: English Voyages and Encounters 1570-1750, New Haven, CT: Yale University Press, 1997; Alan Frost, The Global Reach of Empire: Britain's Maritime Expansion in the Indian and Pacific Oceans 1764-1815, Melbourne: Melbourne University Press, 2003. While this article focuses on the British context, other empires also had Pacific imperial ambitions. For the Spanish perspective see Rainer Buschmann, Iberian Visions of the Pacific Ocean, 1507-1899, Houndmills: Palgrave MacMillan, 2014. For the French see John Dunmore, Visions and Realities: France in the Pacific 1695-1995, Waikanae: Heritage Press Limited, 1997.

5 Some were continental footholds, such as Port St Julian in Patagonia. Other important island stopovers included Juan Fernandez Island, the Ladrones (Marianas), and, later in the eighteenth century, the Falkland Islands. Voyages approaching from the Indian Ocean, while less frequent, often stopped at Batavia (Jakarta, Java).

6 As will be discussed later in this article, geographical maps, marine charts and plans are different cartographic materials intended for distinct purposes. For ease and simplicity, I will use 'map' in a general sense for the body of cartographic materials made to depict Pacific space. When appropriate, I will use 'chart' or 'plan' with regard to specific items.

7 For a recent treatment of the search for longitude see Richard Dunn and Rebekah Higgitt, Ships, Clocks, and Stars: The Quest for Longitude, London: Harper Design and National Maritime Museum, 2014. For a combined art-historical and history-of-science interpretation see Katy Barrett, 'The wanton line: Hogarth and the public life of longitude', PhD dissertation, University of Cambridge, 2013. 
imperial motives of states affected the portrayal and persistence of geographic features. A map, and the knowledge derived from it, were forged from caution and compromise, a point that will be borne out in a case study of the mapping of a geographic enigma, Pepys Island.

Just as islands are difficult to place on maps, cartography is difficult to place within the history of science. The history of cartography remains a niche field of study, one that is rich yet insular and not well integrated into adjacent fields. ${ }^{8}$ Scholars across the discipline of history have recognized Harley's call to view maps as objects of power knowledge, material artefacts imbued with the implicit and explicit biases of the people and societies that formed them. ${ }^{9}$ However, few scholars have taken on the challenge of utilizing maps and charts as sources essential to the integrated study of empire, exploration and science. ${ }^{10}$

Those works that do engage with cartography tend to cover the late eighteenth and the nineteenth centuries, when cartography was becoming a distinct, regulated discipline. ${ }^{11}$

8 This is not necessarily true for the related field of navigation, which, of course, uses charts. A recent overview is Mark Denny, The Science of Navigation: From Dead Reckoning to GPS, Baltimore: Johns Hopkins University Press, 2012. Similarly, exploration is largely accepted as part of the history of science, although the chronological focus on most studies is from the late eighteenth century onward. See Kapil Raj, '18th-century Pacific voyages of discovery, "big science", and the shaping of an European scientific and technological culture,' History and Technology (2000) 17, pp. 79-98. An exception is Bronwen Douglas, Science, Voyages, and Encounters in Oceania, 1511-1850, Houndmills: Palgrave MacMillan, 2014.

9 J.B. Harley's most famous articles are 'Maps, knowledge, and power', in Denis Cosgrove and S. Daniels (eds.), The Iconography of Landscape: Essays on the Symbolic Representation, Design and Use of Past Environments, Cambridge: Cambridge University Press, pp. 277-312; 'Deconstructing the map', Cartographica (1989) 26(2), pp. 1-20; 'Silences and secrecy: the hidden agenda of cartography in early modern Europe', Imago Mundi (1998) 40, pp. 57-76. A sampling of Harley's articles and chapters are collected in J.B. Harley, The New Nature of Maps: Essays in the History of Cartography (ed. Paul Laxton), Baltimore: Johns Hopkins University Press, 2001. For more on Harley's turn to map as textual criticism and discourse analysis see Matthew Edney, 'The origins and development of J.B. Harley's cartographic theories', Cartographica (2005) 40(1-2), pp. 1-143. For a non-anglophone view of Harley's theories see Sebastián Díaz Ángel, 'Aportes de Brian Harley a la nueva historia de la cartografía y escenario actual del campo en Colombia, América Latina y el mundo', Historia Crítica (2009) 39, pp. 180-200. For a recent analysis of Harley's continuing, yet cursory, influence see Matthew Edney, 'Cartography and its discontents', Cartographica (2015) 50(1), pp. 9-13. Finally, it should be noted that Harley drew heavily on Foucault's ideas of power knowledge, an explanation of which is in Michel Foucault, Power/Knowledge (ed. Colin Gordon), New York: Random House, 1980.

10 There are, of course, exceptions. For example, see Paul Mapp, The Elusive West and the Contest for Empire, 1713-1763, Chapel Hill: University of North Carolina Press, 2011; Neil Safier, Measuring the New World: Enlightenment Science and South America, Chicago: The University of Chicago Press, 2008; Pinar Emiralioglu, Geographical Knowledge and Imperial Culture in the Early Modern Ottoman Empire, Farnham: Ashgate, 2014.

11 This chronological focus has contributed to the perception of cartography as a 'singular, universal activity', an ideal. Matthew Edney, 'Field/map: a historiographic review and reconsideration', in Kristian H. Nielsen, Michael Harbsmeier and Christopher J. Ries (eds.), Scientists and Scholars in the Field: Studies in the History of Fieldwork and Expeditions, Aarhus: Aarhus University Press, 2012, pp. 431-456, 431. In terms of Pacific exploration history, the emphasis on the late eighteenth and the nineteenth centuries has much to do with the significant focus on the voyages of Captain Cook and those of the officers he trained, like George Vancouver. For more on the chronological biases of Pacific exploration history see Jane Samson, 'Exploring the Pacific world', in Dane Kennedy (ed.), Reinterpreting Exploration: The West in the World, Oxford: Oxford University Press, 2014, pp. 154-171. For a discussion of how the concepts of 
Earlier maps and mapping practices, with their wandering continents and decorative elements, are too often left outside the discussion of knowledge practices due to their seeming incongruence with larger narratives of the development of natural philosophy and experimentation. ${ }^{12}$ In short, current expectations of what maps are and how they function has limited the integration of maps as sources into the history of science, especially for topics dating to before 1800 .

The relative absence of maps in the history of science is all the more jarring due to the prevalence of the study of space as a factor in knowledge production in recent years. Thanks to the wider attention to space in the discipline of history and the cross-disciplinary work of historical geographers, the local places in which science is practised and the circuits through which knowledge passed have become major foci of analysis. ${ }^{13}$ Corollary to space, objects have also gained prominence as a methodology for probing the creation and mobility of knowledge. ${ }^{14}$ One way these two turns have collided is in the study of circulation, but for the most part these turns, the material and the spatial, have been distinct. ${ }^{15}$

Maps, then, offer one way to combine these two trends. They are objects which create space(s) and circulate through space(s); their study can lead to laying bare the power structures they conceal, depend upon and sustain. This article is a preliminary attempt

exploration and explorer were changing in the eighteenth century see Katherine Parker, 'The savant and the engineer: exploration personnel in the Narbrough and Anson voyage accounts', Terrae Incognitae (2017) 49(1), pp. 6-20.

12 Edney describes this process as rejecting 'Science-with-a-capital-s' while reifying 'Cartography-with-acapital-c' within 'both map and science history'. Cartography remains a stubborn monolith in much scholarship, as opposed to a historicized social process. Edney, op. cit. (11), p. 432.

13 To focus on an eighteenth-century sampling, Charles W.J. Withers, Placing the Enlightenment: Thinking Geographically about the Age of Reason, Chicago: The University of Chicago Press, 2007; Charles W.J. Withers and Robert J. Mayhew, 'Geography: space, place and intellectual history in the eighteenth century', Journal for Eighteenth-Century Studies (2011) 34(4), pp. 445-452; David N. Livingstone and Charles W.J. Withers (eds.), Geography and Enlightenment, Chicago: The University of Chicago Press, 1999. For an overview of the burgeoning literature see James A. Secord, 'Knowledge in transit', Isis (2004) 95, pp. 654672; the special issue on historical geographies of science, BJHS (2005) 38(1); Diarmid A. Finnegan, 'The spatial turn: geographical approaches in the history of science', Journal of the History of Biology (2008) 41, pp. 369-388. Pacific places under consideration as sites of knowledge production include ships, beaches and islands, among others. For ships see Richard Sorrenson, 'The ship as a scientific instrument in the eighteenth century', in Tony Ballantyne (ed.), Science, Empire and the European Exploration of the Pacific, Farnham: Ashgate, 2004, pp. 123-138. For other sites of Pacific knowledge creation see Douglas, op. cit. (8) For a study of island-like places, mountaintops, see Denis Cosgrove and Veronica Della Dora (eds.), High Places: Cultural Geographies of Mountains, Ice and Science, London: Taurus, 2008.

14 For discussion of the material turn and knowledge production see Pascal Schillings and Alexander van Wickeren, 'Towards a material and spatial history of knowledge production: an introduction', Historical Social Research (2015) 40, pp. 203-218, 206; Liliane Hilaire-Perez, 'Technology as a public culture in the eighteenth century: the artisan's legacy', History of Science (2007) 45, pp. 135-153; John Patrick Greene, 'French encounters with material culture of the South Pacific', Eighteenth-Century Life (2002) 26(3), pp. 225-245.

15 On separate turns, see Schillings and Van Wickeren, op. cit. (14), pp. 205-208. Examples of studies which combine the turns include Kapil Raj, Relocating Modern Science: Circulation and the Construction of Knowledge in South Asia and Europe, 1650-1900, Houndmills: Palgrave Macmillan, 2007; Diarmid A. Finnegan and Jonathan Jeffrey Wright (eds.), Spaces of Global Knowledge: Exhibition, Encounter and Exchange in an Age of Empire, Farnham: Ashgate, 2015. 
to see how objects create space via their manufacture and circulation, to marry a site and an object of knowledge production, in order to examine how the practice of mapmaking conditioned the construction of a specific piece of knowledge - an island.

By highlighting one part of the production process - the creation of the material map once information has returned to London - we can better understand the practical conservatism inherent to early modern mapmaking which led to the persistence of geographic enigmas; in this case, the enigma is Pepys Island, an island that never existed yet proved significant to British imperial ambitions in the Pacific for the length of the eighteenth century. Furthermore, Pepys Island is particularly instructive because it is a piece of 'rejected knowledge'; rather than view it as error, however, we learn more from the paper island by examining precisely who made it and how it was made and sustained. ${ }^{16}$ Created in 1684 and for the most part discarded by 1773, Pepys Island challenges a progressive, corrective and cumulative view of cartography that is still endemic. The island's rise and demise offer a microcosm of the larger process of the sociocultural (un)making of knowledge.

\section{The practical and economic limitations of early modern mapmaking}

The persistence of geographic enigmas prior to the late eighteenth century stems from a combination of the quotidian practices of mapmakers and the sources available about a specific region. Market demand led mapmakers to use a limited library of sources and hypotheses to discern and place geographic features. These sources affected the credibility of some of these features, allowing them to persist lest the mapmaker be revealed as too hasty or radical in his revisions - caution paired with conjecture conditioned the form and function of cartography. As Felipe Fernández-Armesto writes, the Pacific offered 'an impressive paradox: the more people learned about the world, the further their credulity stretched'. ${ }^{17}$ I argue that their credulity was not stretched so much as it operated on varying scales depending on the region in question. Some areas of the world were regularly and thoroughly traversed, increasing the number and quality of descriptions about those areas and lowering the expectation and utility of new discoveries. Others, like the Pacific, were assumed to yield up such discoveries, if only they could be safely and reliably recorded.

Before we continue, it is helpful to distinguish between geographical maps, showing terrestrial space based on latitude and longitude and usually intended for reference purposes, and marine charts, used for navigation while at sea. ${ }^{18}$ Each were crafted with specific conventions in mind. For example, it was typical of marine charts to include

16 The article is an attempt to address the 'asymmetrical handling of rejected and accepted knowledge' to better examine the social construction of knowledge. Steven Shapin and Simon Schaffer, Leviathan and the Air-Pump: Hobbes, Boyle, and the Experimental Life, Princeton, NJ: Princeton University Press, 1985, p. 11.

17 Felipe Fernández-Armesto, Pathfinders: A Global History of Exploration, Oxford: Oxford University Press, 2006, p. 292.

18 There are other types of map too, like property plans, which were understood to be at a much higher resolution of detail than geographical maps. For more on generic versus specific types of 'map' see Edney, op. cit. (11), pp. 432-433. 
sounding depths and to indicate otherwise hidden sandbars or shoals with stippling; they seldom, if ever, depicted inland features and their coastlines were calculated at a different level of accuracy than coasts on geographical maps. ${ }^{19}$ Additionally, to be useful in calculations of distance and direction, charts tended to focus on smaller areas, while geographic maps could cover entire regions, or the entire world. Thus map users would select the sort of map they desired for a specific purpose.

The differences in the function and utility of maps and charts underline a larger epistemological point. Similar to natural philosophers conducting experiments, mapmakers valued direct observation as a vital source of information. However, geographic observation was not necessarily repeatable; the process of establishing facts in geography differed from that in other branches of natural philosophy. ${ }^{20}$ Furthermore, the British mapmakers examined here, and European mapmakers in general, were not travellers. They acted as repositories, dependent on others' accounts and measurements. Mapmakers understood that they were receiving mediated information, which they then would compare and collate with other sources, like printed works, manuscript sketches and mariner testimony. The finished product often masked the social and material complexity that made it, presenting a deceptively composed geography that let a viewer feel they were seeing a space as it is, as opposed to the hypothetical geography the mapmaker knew it to be.

In the case of the Pacific and its approaches, the differentiation between geographical maps and marine charts was not clear-cut. For map users, those headed to the area tended to consult widely amongst the few sources available, regardless of whether they were intended for navigation specifically. For mapmakers, the ocean's size and distance from Europe meant that few sources made it back to Britain. Those charts that did exist most likely had to be gathered from rival empires, a difficult task as the Spanish, Portuguese and Dutch had tightly controlled geographic management systems. ${ }^{21}$ Those voyage accounts that were available were riddled with partial, erroneous or missing measurements, possible but unsubstantiated land sightings, and garbled descriptions due to damage or loss at sea.

Additionally, economic and material restrictions worked against the consistent and frequent review of geographic features. Making a map from scratch involved surveying

19 A good overview of the production and sale of marine charts can be found in Coolie Verner, 'John Seller and the chart trade in seventeenth-century England', in Norman J.W. Thrower (ed.), The Compleat Plattmaker: Essays on Chart, Map, and Globe Making in England in the Seventeenth and Eighteenth Centuries, Berkeley: University of California Press, 1978, pp. 127-157; A.H.W. Robinson, Marine Cartography in Britain: A History of the Sea Chart to 1855, Oxford: Oxford University Press for Leicester University Press, 1962.

20 Matthew H. Edney, 'Mathematical cosmography and the social ideology of British cartography, 17801820', Imago Mundi (1994) 46, pp. 101-116; Edney, 'Reconsidering Enlightenment geography and mapmaking: reconnaissance, mapping, archive', in Livingstone and Withers, op. cit. (13), pp. 165-198.

21 For an overview of these systems see, for Spain: Antonio Acosta Rodríguez, Adolfo González Rodríguez and Enriqueta Vila Vilar (eds.), La Casa de la Contratación y la navegación entre España y las Indias, Seville: Universidad de Sevilla, 2003; for Portugal: A. Teixeira de Mota, 'Some notes of the organization of the hydrographical services in Portugal before the beginning of the nineteenth century', Imago Mundi (1976) 28, pp. 51-60; for the Dutch: Günter Schilder, 'From secret to common knowledge: the Dutch discoveries', in John Hardy and Alan Frost (eds.), Studies from Terra Australis to Australia, Canberra: Highland Press, 1989, pp. 71-84, 250-253. 
and/or referencing existing maps and geographic descriptions, drafting manuscripts, engraving on copperplate, and printing and colouring. In the 1650-1750 period, this process could cost over $£ 1,400$ for a map of England and Wales. ${ }^{22}$ In England, just the engraving of a small county map could cost eight pounds, with total print production at twenty pounds. Typically, maps sold for roughly sixpence uncoloured, a shilling coloured. Thus a mapmaker would need to sell roughly four hundred coloured impressions to make a profit, but print runs usually averaged only between two hundred and three hundred copies. ${ }^{23}$

As private businessmen, many mapmakers unsurprisingly sought ways to cut the cost of production, which had an effect on the details included on the map itself. Unless employed by a state entity or a company, mapmakers had to seek out patrons or advertise subscription schemes. ${ }^{24}$ Some chose to avoid surveying and instead depended on descriptions and coordinates from other maps. Another cost-saving measure was to reuse plates, which a mapmaker could inherit or buy. ${ }^{25}$ An engraver could bang out imperfections in copper plates, change names, and update small faults. However, larger problems could not be changed without a new plate, which was expensive and required many hours of labour to engrave. Thus the pursuit of lower production costs often led to the persistence of older geographic ideas.

In order to better understand how British mapmakers approached and utilized their sources, let us examine a map that we will return to in reference to Pepys Island. In 1711, the directors of the South Sea Company commissioned Herman Moll to make a map showing their newly awarded areas of trade (Figure 1). The joint-stock South Sea Company (SSC), the brainchild of Robert Harley, soon to be the Earl of Oxford, was a means to fund Britain's unsecured debt, a debt that had grown alarmingly during the War of Spanish Succession. The company's charter explained that the SSC was to have, 'for ever, the sole Trade and Traffick' in a territory which stretched from the Orinoco river to Tierra del Fuego, up the coast of western South America, to a distance of three hundred leagues out to sea.

Since the early seventeenth century, the Dutch East India Company (VOC) and the EIC exercised exclusive control over navigation east of the Cape of Good Hope and west via the Straits of Magellan. However, when Dutch merchants Willem Schouten and Jacob Le Maire sailed round Cape Horn in 1615-1617, they opened a non-regulated passage to the South Seas. It also made the southern Atlantic, and any islands lying near the passage round Cape Horn, strategically important, hence the SSC's interest in their

22 Estimations of map pricing come from Mary Sponberg Pedley, The Commerce of Cartography: Making and Marketing Maps in Eighteenth-Century France and England, Chicago: The University of Chicago Press, 2005, p. 70.

23 David Woodward, 'English cartography, 1650-1750, a summary,' in Thrower, op. cit. (19), pp. 159193, 166.

24 Pedley, op. cit. (22), pp. 13, 34.

25 As just two examples see 'PROPOSALS For the last general Sale of Mr. OGILBY's Books, Maps, Roads, \&c. intended to be opened on the 23th Day of March 1690/1 by Robert Morden ...', BL Harley MS 5946, f. 186. Moses Pitt used his access to the plates from a Dutch atlas by Jans Jansson as a way to gain authority. See 'PROPOSALS FOR PRINTING A NEW ATLAS. MOSES PITT of London, Bookseller', BL Harley MS 5946, f. 191. 


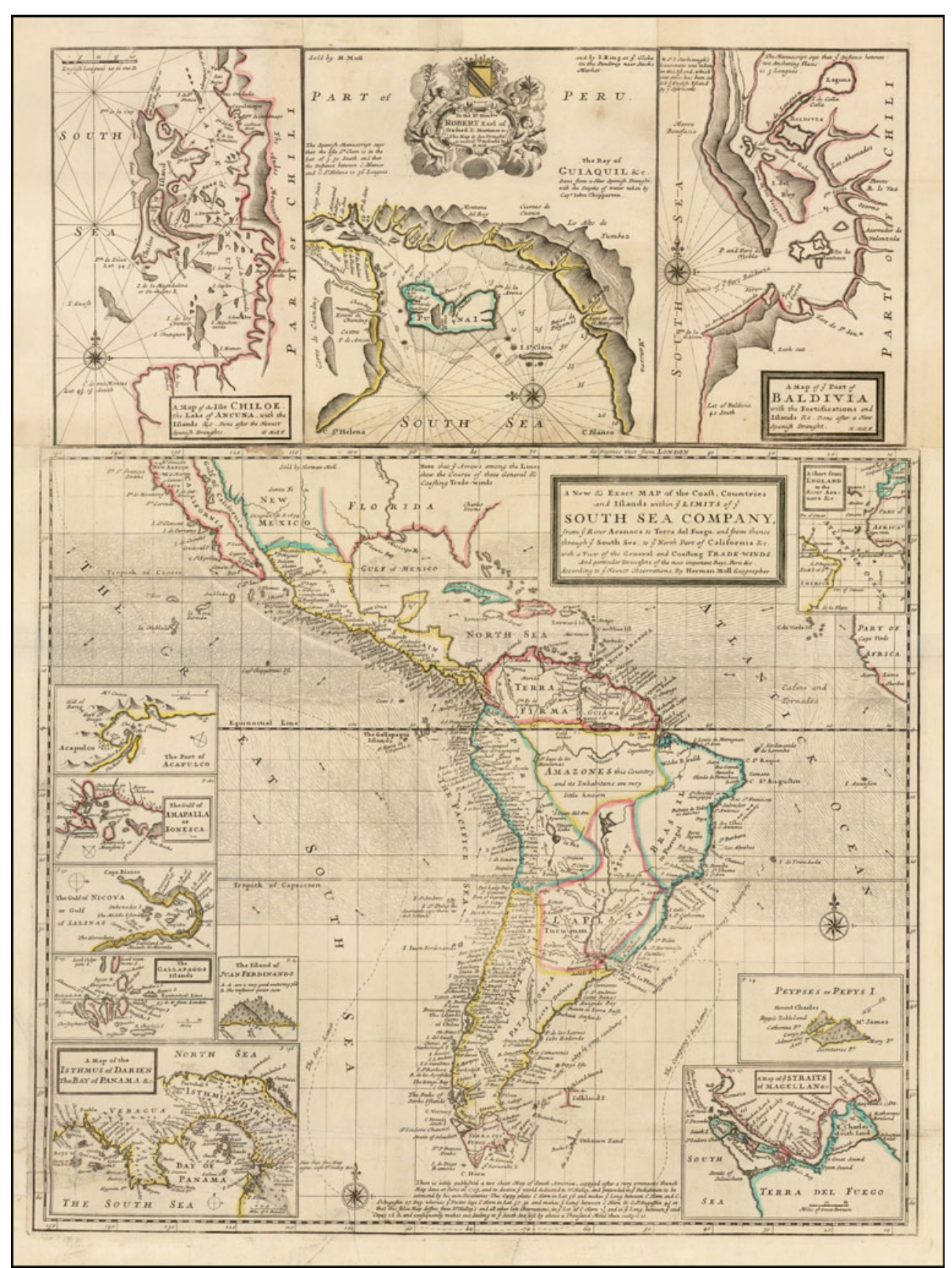

Figure 1. Herman Moll, A New \& Exact Map of the Coast, Countries and Islands within ye Limits of ye South Sea Company, London: Herman Moll, 1711, $26 \times 19.5$ inches. Image reproduced with permission of Barry Lawrence Ruderman Antique Maps Inc. 
new, exclusive trading zone. Crucially, the SSC also had control over all lands that would be found within their bounds, and could commission voyages to explore those lands if they saw fit. ${ }^{26}$

As part of ultimately fruitless preparations for a voyage that never sailed, the directors sought to learn more about the region they now nominally controlled. ${ }^{27}$ To this end, they sought out Moll. Moll had established a reputation for himself as a Pacific expert by engraving the maps in several voyage accounts. Moll was born in Bremen and migrated to England sometime before $1678 / 1679$, when he is recorded as working as an engraver for the map publisher Moses Pitt. Moll was part of a wider circle of associates who included intellectuals and privateers like Robert Hooke, John Locke, Daniel Defoe, Jonathan Swift, William Dampier and Woodes Rogers. ${ }^{28}$

The memoir Moll prepared to accompany the map listed some of his sources - accounts from several buccaneer expeditions and one naval voyage which traversed the waters near western South America over the previous half-century. The majority of these

say little of either side of the Continent, and what they do say is without Order. Funnell [a buccaneer] is the most particular, but then he follow'd an old Spanish Draught, which though it appears to be very regular in naming Ports, Harbours, Rivers and Creeks, yet it is not very certain. $^{29}$

Moll's complaints are not unexpected; as a mapmaker, it behoves his profit margin to constantly complain that more knowledge is necessary to create improved - i.e. newer - maps. However, his complaint also sheds light on his root problem: too few sources and a paucity of reliable, recent information allowed for incomplete and uncertain interpretations, a perennial challenge in mapmaking that was amplified by the remoteness of the Pacific.

On the map itself, Moll places text south of Cape Horn. He criticizes copies of 'lately published a two sheet Map of South America, coppyed after a very erroneous French Map done at Paris in 1703 and to deceive ye world dedicated to Dr Halley'. Moll is most likely referring to a map by Charles Price, Moll's competitor. ${ }^{30}$ Dr Halley is the natural philosopher Edmond Halley, recently returned from, and producing maps about, the waters near Cape Horn. Moll is particularly aghast at Price's errors in the placement of this important feature. Cape Horn on

this false Map differs from Dr Halley's and all other late Observations, in ye Lat[itude] of C. Horn $1 \frac{1 / 2}{2}$ and in ye Long[itude] between ye said Capes [Cape Horn and Cape St

26 BL MS LOAN 25/49C, 'ABSTRACT of the Charter of the Governour and Company of Merchants of Great Britain, Trading to the South-Seas, and other Parts of America, and for Encouraging the Fishery', London: John Barber, 1711, 4-5.

27 BL Add MS 25494, ff. 178, 187.

28 Dennis Reinhartz, The Cartographer and the Literati: Herman Moll and His Intellectual Circle, Lewiston: The Edwin Mellen Press, 1997; Gillian Hutchinson, 'Herman Moll's view of the South Sea Company', Journal for Maritime Research (2011) 6, pp. 87-112.

29 Herman Moll, A View of the Coasts, Countries and Islands Within the Limits of the South-Sea Company, London: J. Morphew, 1711, preface.

30 Charles Price, SOUTH AMERICA Corrected from the Observations Communicated to the ROYAL SOCIETY'S of LONDON and PARIS, London: Sold by T. Brandeth \& G. Wildey, c.1710. 
Augustin] 18 D[egrees] and consequently makes our sailing to ye South Seas less by above a Thousand Miles than really it is. ${ }^{31}$

Beyond taking an open shot at a competitor, Moll is also making a commentary on the availability of geographic knowledge. He is taking Price to task for offering erroneous information to consumers, even though the vast majority of his readers most likely would never need a practical map for navigational purposes. It is a matter of professional accountability to make calculations and source citations as transparent and accurate as possible, not to mention to avoid appropriating the names of luminaries like Halley.

On his two-sheet map of South America, which resembles the SSC map, Moll includes a further gripe, one which reminds us of the mixed nature of cartographic materials used in preparing to sail to the Pacific, a theme that will be repeated in the study of Pepys Island. Moll writes of his competitors' maps, 'every body may easily judge what a Dangerous consequence these maps may produce, if ever they should be us'd at Sea, and ye wrong notions they must give others at land are no less apparent' ${ }^{32}$ Moll is correct that such works could end up at sea. Naval officers and those in command of merchant marine vessels had to supply themselves with instruments and charts; the Royal Navy's Hydrographic Office would not be founded until 1795. ${ }^{33}$ Officers of naval voyages frequently recorded their preparation for voyages, citing charts from various European powers, maps in voyage accounts, text in voyage accounts and sheet maps. This mixed use is indicative of the familiarity with geographic knowledge at the time, but also of the limited source bank for the Pacific region.

To summarize, British mapmakers relied on the work of rivals and allies alike to inform their own placement of features while creating products for an open market. Map consumers, including savants, naval officers and government officials, were geographically conservative. If a mapmaker added uncorroborated details to a new chart, or eliminated previously accepted geographic features with no explanation, it could lead a voyage astray, not to mention ruin one's reputation with customers. Geographic knowledge was a scarce, valued commodity subject to considerable scrutiny, yet its very scarcity also made those creating new maps more likely to trust in dubious sources and maintain uncertain features. This paradox was additionally compounded by personal and political motives, a topic best pursued via an example of an island that never existed except on paper.

\section{Pepys Island}

As the previous section explained, Pacific geographic enigmas were not fanciful flights of imagination; rather, persistent geographic features were maintained as a result of the use

31 Herman Moll, A New \& Exact Map of the Coast, Countries and Islands within ye Limits of ye South Sea Company, London: Herman Moll, 1711.

32 Herman Moll, Map of South America, London: Herman Moll, c.1712.

33 The latest treatment of the Hydrographic Office is from Megan Barford, 'Naval hydrography, charismatic bureaucracy, and the British military state, 1825-1855', PhD dissertation, Cambridge University, 2016. 
of a limited source bank and the practices of early modern mapmaking. A geographic enigma, as used by Moscoso et al. in their 2013 edited collection, refers to those chimeric features associated with access to the Pacific; a Northwest Passage and the southern route round South America were early modern obsessions due to the perceived riches offered by an open waterway to Chinese trade. ${ }^{34}$ The association with access to the Pacific is apt in this case, as Pepys Island was supposed to be off the coast of what is now Argentina in the South Atlantic, precisely along the route of most European ships entering the Pacific.

Modern constructions of space are often grafted onto historical predecessors and are used to separate fields of inquiry, as is the case with Atlantic and Pacific history. This is unfortunate, for historical actors did not necessarily engage in the same geographic dissection of their worlds. For the British in the late seventeenth and mid-eighteenth centuries, the Pacific, or the South Seas, was approached from the east. ${ }^{35}$ The waters surrounding the Straits of Magellan, the Straits of Le Maire and Cape Horn were considered linked to the larger ocean to the west. Pepys Island supposedly lay in this approach and as such was thought of by European sailors as a part of a South Seas journey and by European governments as a useful foothold in controlling access to the Pacific.

The first mention of Pepys Island comes from the buccaneer Ambrose Cowley. Cowley was one of an influx of buccaneers to enter the South Seas in the last two decades of the seventeenth century. Pirates and privateers were so numerous in the Caribbean in the late seventeenth century that some sought less crowded waters, crossing the Isthmus of Panama into the South Seas. Whereas the crews of these ships were international in origin, the majority of the printed accounts to come from these voyages were English; they formed a 'literate and literary buccaneering fraternity'. ${ }^{36}$ The most famous of these buccaneer writers was undoubtedly Moll's associate William Dampier, who leveraged his experiences during three circumnavigations to write popular accounts that combined the adventures of privateering with entirely new natural-historical and geographical observations. ${ }^{37}$

34 Sabrina Guerra Moscoso (ed.), Enigmas de las Américas: Geografía, Expediciones y Cartografía, Quito: Universidad San Francisco, 2013, esp. p. 7.

35 O.H.K. Spate, "“South Sea” to "Pacific Ocean", in Ballantyne, op. cit. (13), pp. 3-9.

36 William Hasty, 'Piracy and the production of knowledge in the travels of William Dampier, c.16791688', Journal of Historical Geography (2011) 37, pp. 40-54, 53. There were considerably more French ships in the South Seas in this period than English, but they did not publish as frequently. Williams argues that this could be due to the sensitive diplomatic situation or the 'mundane nature of the trade'. Williams, op. cit. (4), pp. 135-136. For more on South Seas piracy see Peter Gerhard, Pirates of the Pacific: 15751742, Lincoln: University of Nebraska Press, 1990.

37 Dampier is the first naturalist chronicled in Glyndwr Williams's latest book, Naturalists at Sea: Scientific Travellers from Dampier to Darwin, New Haven, CT: Yale University Press, 2013. See also Anton Gill, The Devil's Mariner: William Dampier, Pirate and Explorer, London: Michael Joseph, 1997; Gerald Norris (ed.), The Buccaneer Explorer: William Dampier's Voyages, London: The Boydell Press, 1994; Diana Preston and Michael Preston, A Pirate of Exquisite Mind: The Life of William Dampier, Explorer, Naturalist and Buccaneer, London: Doubleday, 2004; Adrian Mitchell, Dampier's Monkey: The South Seas Voyages of William Dampier, Kent Town: Wakefield Press, 2010; Alex S. George, William Dampier in New Holland: Australia's First Natural Historian, Hawthorn: Bloomings Books, 1999; Andrea Sáerz-Arroyo, 
In 1683 Cowley, accompanied by Dampier, sailed on a South Seas voyage as sailing master. In $47^{\circ} 40^{\prime} \mathrm{S}$ latitude, the crew spotted uncharted land. In his manuscript memoir, Cowley noted, 'the Island seemed very pleasant to the eye with many woods, I may as well say the whole land was woods'. It was inhabited by a company of fowls the size of geese who dive-bombed the sailors and tasted good, only 'somewhat fishy'. Most importantly, Cowley reported that there was a harbour with space for five hundred ships. Cowley was all in favour of a landing, but his shipmates were having none of it - 'I would have had them stood upon a wind all night, but they told me they were not come out to go upon Discovery. ${ }^{3} 8$

Cowley finishes the entry by saying that they also saw another island as they sailed away, 'which made me think'o them to be the Sibble D'wards'. ${ }^{39}$ The reference is to the Sebald de Weert Islands, first sighted by Dutch navigator Sebald de Weert in 1600 on his return from the Straits of Magellan. These islands were actually part of the Falklands archipelago, whose first European contact has long been in dispute yet whose name derives from the fifth Viscount Falkland, then treasurer of the navy, after the first Englishman, buccaneer John Strong, landed on the main island in 1690.40 The favourable description and mention of the Sebald de Weerts is all Cowley includes in his journal, which was written retrospectively after Cowley returned to England in 1686. He had fled his ship in the South Seas, leaving his original notes behind. Thus the first report of the new island came via a secondary inscription based on a memory of a voyage considered too troubled to continue, an example of the problematic passages through which geographic knowledge is transmitted.

Once returned to England, Cowley came into contact with a figure well known to South Seas buccaneers, William Hacke. Hacke was one of the final, yet best-known, members of the Thames school, which specialized in maritime cartography and is best known for portolan charts in the Italian or Mallorcan style. ${ }^{41}$ By the mid-1680s, Hacke had forged a considerable reputation by reproducing lavish copies of a South Seas derrotero, or book of charts, that Bartholomew Sharpe, another privateer, had captured from a Spanish ship.

In 1687, Hacke created a roll map of the island; it is drawn as a bird's-eye view. There are two islands; the larger is to the east with a large hill, Mt James. A smaller, crescentshaped island is to the west, with a strait running between the two. The full title of the map is 'A description of Mr. Secretarie, Pepys; his Island discovered in the year 1683: This Island was discovered by William Ambros Cowley who called it after this Name'. ${ }^{42}$ The island is listed as lying at $47^{\circ} 40^{\prime} \mathrm{S}$ and eighty leagues from the shore of

Callum M. Roberts, Jorge Torre, Micheline Cariño-Olvera and Julie P. Hawkins, 'The value of evidence about past abundance: marine fauna of the Gulf of California through the eyes of 16th to 19th century travellers', Fish and Fisheries (2006) 7, pp. 128-146.

38 BL Sloane MS 54, f. 5.

39 BL Sloane MS 54, f. 5.

40 Tim Beattie, British Privateering Voyages of the Early Eighteenth Century, Woodbridge: Boydell, 2015, p. 42.

41 Thomas R. Smith, 'Manuscript and printed sea charts in seventeenth-century London: the case of the Thames school', in Thrower, op. cit. (19), pp. 45-100.

42 BL Add MS 17940B. 
Patagonia. Later in the title, Hacke mentions Cowley's harbour, except now it is big enough for a whopping thousand ships. There was no space, it seems, to include Cowley's hypothesis that the island he saw might have some relation to the Sebald de Weert archipelago, which was usually shown several degrees south of Pepys Island's supposed location. Instead, Hacke eradicated any hint of equivocation and fashioned a discovery act, one that the viewer can mimic by looking at the roll map.

Cowley, or more likely Hacke, named the island after Samuel Pepys. Pepys was a prescient choice, for he served as chief secretary to the Admiralty from 1673 to 1679 and from 1684 to 1689 , and was also a prominent member of the Royal Society, acting as its president from 1684 to 1686 . Thus he was still chief secretary and had just finished his tenure as head of the nation's leading scientific body when Hacke made his roll map, which was intended for elite audiences. When combined with the other toponyms, it is clear that Hacke was trying to lend legitimacy to an island that had been sighted on a voyage that was of dubious legality. Hacke also typically dedicated his atlases to men at the highest echelons of naval and government administration; these toponyms may have been bids for more commissions from patrons.

Hacke began to include the island in his atlases, further disseminating news of the place and suggesting that it was, or should be, an English possession. In 1699, Hacke, now 'Capt. William Hacke', edited a compilation of voyage accounts which included Cowley's journal. ${ }^{43}$ As with the roll map, in this version of the journal, Cowley is said to have named the uninhabited isle Pepys Island. Again, there is no mention of the Sebald de Weerts - that is, no mention that the original claim to the island could be anything but a novel, and English, discovery. The world map included in the book, which shows Cowley's track, is one of the first printed maps to show Pepys Island, just off the Patagonian coast at $47^{\circ} \mathrm{S}$. In addition, the book includes a larger-scale rendition of 'Peypses Island', as one inset of a map which includes Juan Fernandez Island, the Cape of Good Hope, and the Nutmegg Island. The islands look much like they did in Hacke's previous works, although they were engraved by Herman Moll. Together, Hacke and Cowley passed information between them and put it into manuscript and print form. In the journey between men and words, the island had grown, was named and was now available to the wider reading public, not just the elite patrons who would have seen Hacke's manuscript atlases. It was literally framed, in the inset, as one of several stopping points in global commerce, much like the Cape of Good Hope and the Spice Islands.

Edmond Halley, who was already mentioned in reference to maps of the region, served a vital role in fixing Pepys Island in geography. He also shows how reference to geographic materials of different types leads to the persistence of geographic features. Supported by the Admiralty and the Royal Society, Halley sailed twice to the South Atlantic in 1698 and 1699. His journals were not published in his lifetime, but he did, after a third cruise in the English Channel, produce a string of articles for the Philosophical Transactions of the Royal Society and several charts, including A New

43 Capt. William Hacke (ed.), A Collection of Original Voyages, London: James Knapton, 1699. 
and Correct Chart Shewing the Variations of the Compass in the Western \& Southern Oceans (1701) and A New and Correct Sea Chart of the Whole World Shewing the Variations of the Compass (1702). The map of the Western \& Southern Oceans is considered one of the first thematic maps and the first printed isogonic (magnetic variation) map. ${ }^{44}$ The world map also has isogons but, while they swirl across the Atlantic and Indian Oceans, they stop between Japan and Tierra del Fuego. In the middle of this large, open space Halley placed a paragraph of text where he explains, 'I durst not presume to describe the curves of the South Sea wanting accounts thereof', a conservative choice that in this case caused a curtailing, rather than a continuation, of geographic hypotheses. ${ }^{45} \mathrm{He}$ did presume to include Pepys Island, however. It is a tiny speck off the coast of Patagonia at $47^{\circ} \mathrm{S}$ on both maps.

Interestingly, though, Halley did not mention the island in his journals and his ship never sailed anywhere near the supposed location of the island. ${ }^{46}$ This suggests that Halley had seen other maps and read accounts, likely Hacke's collection, that included Pepys Island. When fashioning his own work, he accepted the island as geographic fact, erasing the political context that led Hacke to promote the place. Halley's fame and reputation as a savant lent his map particular credibility amongst his fellow intellectuals. By including Pepys Island, he helped to fix the location and existence of the island and made it more likely to be taken up by others.

A decade after Halley's map, another British mapmaker showed an abiding interest in Pepys Island. This was, of course, Herman Moll. Moll's chart (Figure 1) is important not only because it shows the huge ambition, never followed through, of the SSC, but also because it redefines Pacific space from a place where privateers had plundered to a more defined trade region. His view of the South Seas firmly includes Pepys Island, which is shown as a separate inset in the lower right corner on the map (Figure 2). Moll's first map of Pepys Island had been in Hacke's voyage collection and he had continued to include the island in his intervening works. This inset is largely identical to the 1699 inset, with the small update of the name from 'Peypses Island' to 'Peypses or Pepys Island'. Moll chooses to place the Pepys Island inset in the same corner as a detail of the Straits of Magellan. This is not only because the two features are on the east and south of the larger depicted area, but also because Pepys Island was touted as a likely watering place before braving the dangerous entrance to the western trade ports of South America. The inset, and the larger map, suggest that the British had more control over southern South America than they did in reality. It also helps to negate the claims and trade monopolies of the Spanish. Ironically, the inclusion of Pepys Island made it

44 Alexander Dalrymple published the journal of the first two voyages in Two Voyages made in 1698, 1699 and 1700 By Edmond Halley, London: printed by the author, 1773. They were also included in Alexander Dalrymple (ed.), A Collection of Voyages Chiefly in The Southern Atlantick Ocean, London: printed for the author and sold by J. Nourse, P. Elmsly, Brotherton and Sewell, Jefferys and Faden, A. Dury, 1775. The journal of Halley's third voyage was not published until Norman J.W. Thrower, The Three Voyages of Edmond Halley in the Paramore 1698-1701, London: The Hakluyt Society, 1981. The chart of the Western \& Southern Oceans is reproduced in the Thrower volume.

45 Edmond Halley, A New and Correct Sea Chart of the Whole World Shewing the Variations of the Compass as They Were Found in the Year M.D.CC, London: Mount and Page, 1702.

46 Thrower, op. cit. (44), p. 59. 


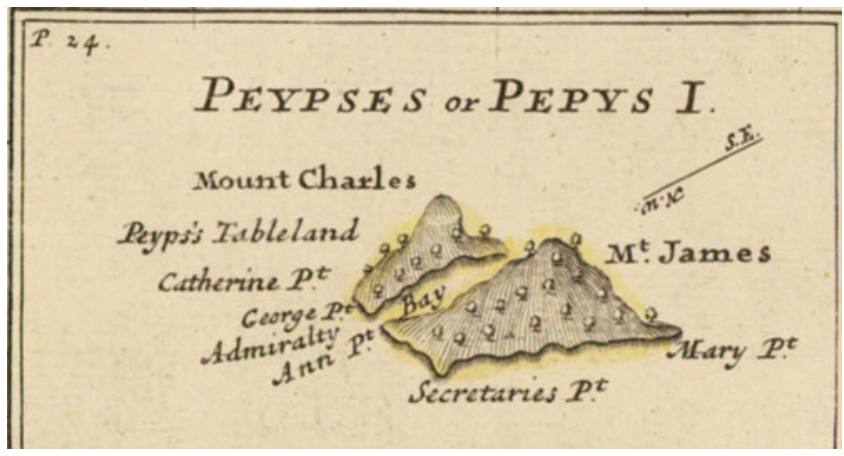

Figure 2. 'Peypses or Pepys Island', inset in Herman Moll, A New \& Exact Map, op. cit.

seem that the British had a clear path to the Pacific, making navigation of the rest of the unknown ocean more achievable.

If Halley's reputation and Moll's maps had provided fixity for Pepys Island, George Anson's voyage twenty years later increased its political profile. In the intervening decades, British involvement in the Pacific waned to the point where, in 1738, when approached about a new voyage to search for the Northwest Passage, First Lord of the Admiralty Charles Wager said, 'a Spirit of that Kind seems to have been asleep for many Years'. ${ }^{47}$ The spirit awoke with a vengeance when Britain declared war on Spain, ostensibly to defend its Caribbean trade. This conflict, known as the War of Jenkins' Ear, would become subsumed within the larger War of Austrian Succession.

As part of the war effort, the Admiralty planned a voyage to the Pacific to harass Spanish trade. They appointed Commodore George Anson to lead the mission. He sailed in 1740, disastrously losing five of his six ships and 1,400 of his 1,900 men in entering and crossing the Pacific. His reputation was saved when he seized the Acapulco treasure galleon in 1743. For his efforts, Anson was appointed to the Board of the Admiralty and hailed as the second coming of Francis Drake.

Although his squadron did not sail in the supposed vicinity of Pepys Island, Anson featured the island in his 1748 voyage account, one of the bestselling books of the century. ${ }^{48}$ After suggesting that more expeditions to the South Seas should be a priority, Anson argues that Britain, with the strongest navy in the world, should seek out new discoveries and clarify existing confusion: 'I cannot desist from the present subject, without beseeching those to whom the conduct of our naval affairs is committed, to endeavour to remove the many perplexities and embarrassments with which the navigation to the South-Seas

47 Letter, Admiral Sir Charles Wager to Arthur Dobbs, 4 March 1737, included in William Barr and Glyndwr Williams (eds.), Voyages in Search of a Northwest Passage 1741-1747, vol. 1: The Voyage of Christopher Middleton 1741-1742, London: Hakluyt Society, 1994, Section I, Doc. 14, p. 50.

48 Glyndwr Williams, 'George Anson's Voyage Round the World: the making of a best-seller', Princeton University Library Chronicle (2003) 64(2), pp. 288-312; Marta Torres Santo Domingo, 'Un bestseller del siglo XVIII: el viaje de George Anson alrededor del mundo', Biblio $3 \mathrm{~W}$, Revista Bibliográfica de Geografía $y$ Ciencias Sociales (2004) 9(531), pp. 1-27. 
is, at present, necessarily encumbered.' With reference to the approach to Patagonia, watering in Brazil was a liability, therefore a priority should be the 'discovery of some place more to the southward, where ships might refresh and supply themselves'. Anson continues, 'And we have in reality the imperfect knowledge of two places, which might perhaps, on examination, prove extremely convenient for this purpose. ${ }^{49}$ One of these is the 'Falkland's Isles', which 'have been seen by many ships both French and English'. The other is Pepys Island. Anson explains that Pepys Island lies at $47^{\circ} \mathrm{S}$ latitude and was charted by Halley; he does not mention that Halley never actually sighted the place. The island

was discovered by Captain Cowley, in his Voyage round the World in the year 1696 [sic]; who represents it as a commodious place for ships to wood and water at, and says, it is provided with a very good and capacious harbour, where a thousand sail of ships might ride at anchor, in great safety; that it abounds with fowls, and as the shore is either rocks or sands, it seems to promise great plenty of fish. ${ }^{50}$

Clearly, Anson had read Cowley's journal as edited by Hacke. He also used Halley's chart, although it is unclear whether he used the chart of the Western \& Southern Oceans or the world map. His recommendation not only popularized the island, but made it a viable and important target for further exploration by the Royal Navy.

Anson would try to follow his own suggestion, but was hindered by the circulation of his voyage account. When, in January 1749, Anson reported to his fellow Admiralty Board members that two sloops were to be fitted out 'to be sent on Discoverys in the Southern Latitude', he was met with intense Spanish suspicion. ${ }^{51}$ As explained in a letter from the Duke of Bedford, Secretary of State for the Southern Department, to ambassador to Madrid Benjamin Keene, the expedition would proceed in two phases. First, it was meant to enact the 'full discovery of Pepys's and Falkland's Islands', in order to better understand the relation of the island groups. This was to be followed by a trip 'into the South Sea, in order to make further discoveries there'. ${ }^{52}$ The Spanish rejected the attempt by the British to frame the voyage as innocent and of universal benefit. The Spanish had read Anson's account and knew that even the clarification of current navigational confusion, as in the case of Pepys Island, could allow the British a gateway to the Pacific. In the words of Spanish minister Joseph de Carvajal, 'neither He nor any one else could be a Stranger to the Rise \& Intent of such an Expedition, since it was so fully explained in the printed Relation of Lord Anson's voyage'. ${ }^{53}$ The Spanish held fast against the plans and the British eventually dropped

49 Richard Walter and Benjamin Robins, with Glyndwr Williams (eds.), A Voyage Round the World in the Years MDCCXL, I, II, III, IV by George Anson, London: Oxford University Press, 1974, p. 96. Anson directed the publication of the account, which was written by Richard Walter, the chaplain on Anson's command, and Benjamin Robins, a fellow of the Royal Society.

50 Walter and Robins, op. cit. (49), p. 97.

51 TNA ADM 3/60, 19 January 1749, as quoted in Williams, op. cit. (4), p. 258.

52 Bedford to Keene, 24 April 1749, BL Add MS 43423, f. 78. Another copy of the letter can be found at TNA SP 94/135, ff. 177-179.

53 Keene to Bedford, 21 May 1749, BL Add MS 43423, f. 86. 
them in order to maintain peace. Pepys Island remained uncertain yet intact, and of considerable interest to both the Spanish and the British.

The final chapter in the search for Pepys Island began after the end of the Seven Years War. On 3 July 1764, the Dolphin and its escort, the Tamar, sailed from Plymouth. Their commander, the Honourable John Byron, was to search for Pepys Island, then to establish a British presence in the Falklands. Byron set out with high hopes:

I had now made eighty degrees easting, which is the distance from the main at which Pepys' Island is placed in Halley's chart, but the great misfortune is that we have no certain accounts at all of this Island. Cowley was the only person that pretended to have seen it, \& all he says of it (for I have now his Voyage before me) is that it lays in the Latt of 47. But mentions nothing of the Longitude he was in at the time, \& at the same time he tells us it has a fine Harbour \&c. he says it blew so hard he could not get into it but stood away to the So[uth]ward. ${ }^{54}$

Byron mentions that he had the Hacke collection at sea; the small octavo volume, over six decades old, was still used as an authority due to the paucity of other sources and thanks to its handy size. After four days of searching, Byron was 'now certain that there could be no such island as is mentioned by Cowley, and laid down by Halley under the name of Pepys' Island'. ${ }^{55}$

Pepys Island did not disappear immediately or completely. Sailors continued to look for it while passing through the area, including those on James Cook's first expedition:

On the $3 \mathrm{~d}$ of January, 1769 , being in latitude $47^{\circ} 17^{\prime} \mathrm{S}$. and longitude $61^{\circ} 29^{\prime} 45^{\prime \prime}$ W. we were all looking out for Pepys' island, and for some time an appearance was seen in the east which so much resembled land, that we bore away for it; and it was more than two hours and an half before we were convinced that it was nothing but what sailors call a Fogbank. ${ }^{56}$

The island, now mere mist, had been displaced from its place in the Pacific canon, as evidenced by its exclusion from the maps in the voyage collection of the Byron, Wallis, Carteret and Cook circumnavigations of the 1760s. ${ }^{57}$ Pepys Island had proven a durable part of geography thanks to its repetition from source to source, a decision made by Halley, Moll and Anson due to the limited number of sources available on the Pacific in the first place. Pepys Island was particularly resilient because it represented 'imperfect knowledge', as Anson put it, in a strategic location. ${ }^{58}$ As long as it remained so imperfectly known, it remained viable. However, Anson's emphasis on its potential utility also made its verification a priority, guaranteeing its ephemerality. While for a

547 December 1764, NMM JOD/58, ff. 48-49.

5510 December 1764, NMM JOD/58, f. 50.

56 John Hawkesworth, An Account of the Voyages Undertaken by the Order of his Present Majesty for Making Discoveries in the Southern Hemisphere, vol. 2, London: Cadell and Strahan, 1773, 44.

57 Hawkesworth, op. cit. (56). The island also continued to have some political valence. One of Argentina's first historians, Pedro de Ángelis, revived the topic of Pepys Island in the mid-nineteenth century. Pedro de Ángelis's 'Apuntes históricos de la Isla Pepys', originally written in 1839, is reproduced in Antonio de Viedma y Basilio Villarino, Diarios de navegación: expediciones por las costas y ríos patagónicos (17801783), Buenos Aires: Continente, 2006, pp. 33-36. At least one scholar in the twentieth century has also taken up the case. C.B. Chambers, BM, 'Where was Pepys Island? A problem in historical geography', Mariner's Mirror (1933) 19(4), pp. 446-454.

58 Walter and Robins, op. cit. (49), p. 96. 
time it had served as a potent symbol of British expansion, by the late eighteenth century there were other islands that filled that purpose. Indeed, it was to be the Falklands, visited by both Byron and the French navigator Bougainville in 1764, which emerged as the (ongoing) touchstone of conflict among the imperial powers, poised as it is as a gateway to the Pacific.

The series of Pacific voyages launched after the Seven Years War overhauled the existing canon of Pacific knowledge, geographic and otherwise. These expeditions were aided by several factors, including improved navigational and sailing technology, an altered political climate that allowed more open access to Pacific waters, and an emergent scientific rhetoric that framed the Pacific as a vibrant, and exotic, laboratory in which to gather natural-historical, botanical and ethnographic knowledge. ${ }^{59}$ No longer restricted by such a limited source bank, mapmakers used their method of compilation to reconsider centuries-old observations in light of new ones. The greatest enigma of all, the hypothesized southern continent, was reduced in size and replaced by the promises of Australia. However, it is important to remember that another enduring enigma, the Northwest Passage, remained elusive and drove the Royal Navy's exploratory agenda into the nineteenth century. Just because mapmakers had new sources did not mean that all geographic questions were immediately, or finally, resolved.

Pepys Island is an interesting case study not because it is exceptional, but because it is representative, both of geographic knowledge and of early modern knowledge production in general. The same process of evaluation, theorizing, comparing and scheming that led Pepys Island to its brief place on maps was the process by which all maps and charts were made prior to the end of the eighteenth century. The consequences of this process, when paired with a scarcity of sources, were amplified for remote regions, especially the Pacific. Cartography was, and still is to a larger extent than we are comfortable admitting, a paradoxical process that depends on conservative compilation paired with creative speculation. Furthermore, the extra-intellectual influences which shaped Pepys Island are indicative of the factors which affect all branches of knowledge during this period.

By revealing the social, material and political complexity that underwrote the cartography of Pepys Island, it is possible to see the ways in which maps are more widely implicated in the history of science. First, the ways in which practical and economic factors impact the content of maps is instructive for studies of other scientific objects, including instruments and books. Second, while historians of science have integrated material and spatial analyses via circulation, it is important to realize that such mobility was often dependent on certain objects, including maps, for orientation and organization. If, as James Secord famously argued, the central question of the history of science is, 'how and why does knowledge circulate?', ${ }^{60}$ then objects designed to facilitate movement, including maps, should be more central to analyses of knowledge mobility.

59 Nicholas Thomas, 'The age of empire in the Pacific', in David Armitage and Alison Bashford (eds.), Pacific Histories: Ocean, Land, People, Houndmills: Palgrave MacMillan, 2014, pp. 75-96. See also Frost, op. cit. (4).

60 Secord, op. cit. (13), p. 655. 
Third, and in a related point, most exploratory voyages in the eighteenth century were driven by geographic questions. Byron's instructions to find Pepys Island are just one example. Another is Cook's secret instructions to seek the southern continent. ${ }^{61}$ These voyages in turn contributed to the development of many nascent disciplines, including botany, natural history, zoology and, of course, cartography, hydrography and geography. Maps, therefore, are intricately entwined across areas of inquiry within the history of science, particularly as it developed in the Pacific region, and should be more widely integrated as sources. They can help us to better understand the interlacing narratives of knowledge production which changed radically in the eighteenth century, due in no small part to encounters with and in the world's largest ocean.

61 J.C. Beaglehole, The Journals of Captain James Cook, vol. 1, Cambridge: Hakluyt Society, 1955, p. cclxxxii. 